\title{
Kontekstualisasi Pembelajaran Filsafat Ilmu pada Program Magister Psikologi Universitas Mercu Buana Yogyakarta
}

\author{
Hastangka ${ }^{1}$, \\ ${ }^{1}$ Magister Psikologi, Universitas Mercu Buana, Yogyakarta, Indonesia \\ E-mail: hastangka@gmail.com ${ }^{1}$
}

\begin{abstract}
Abstrak
Filsafat IImu merupakan salah satu mata kuliah wajib yang diselenggarakan untuk program studi magister Psikologi Universitas Mercu Buana Yogyakarta. Pada dasarnya, Filsafat IImu menjadi salah satu bagian penting pembelajaran untuk mahasiswa semester pertama pada jenjang strata 1 dan strata 2 di perguruan tinggi sebagai fondasi untuk mengenal, memahami, dan mendalami tentang bidang ilmu tertentu yang dipelajari. Filsafat IImu sebagai salah satu cabang filsafat khusus memiliki fungsi dan peran untuk menjadi dasar berpijak dalam memberikan kerangka ontologis, epistemologis, dan aksiologis atas ilmu yang ada dan berkembang dewasa ini. Filsafat IImu diajarkan pada jenjang pendidikan strata 2 sebagai upaya untuk memberikan kerangka berpikir untuk mengembangkan dan mendalami disiplin ilmu yang lebih spesifik dan mendalam. Penelitian ini merupakan salah satu bentuk penelitian tindakan kelas yang akan mendeskripsikan tentang proses pembelajaran Filsafat IImu pada Program Magister Psikologi Universitas Mercu Buana Yogyakarta pada periode tahun 2020 sampai dengan 2021. Tujuan dari penelitian ini ialah untuk memberikan orientasi dan pengenalan model pembelajaran Filsafat Ilmu pada program Strata 2 di Universitas Mercu Buana Yogyakarta. Kontekstualisasi pembelajaran Filsafat IImu untuk bidang disiplin ilmu di luar Filsafat menjadi penting dilakukan. Metode penelitian ini menggunakan metode kualitatif. Sumber data yang digunakan dalam penelitian ini menggunakan sumber data dari buku, jurnal ilmiah, dan hasil wawancara kepada mahasiswa. Analisis data ini menggunakan analisis kritis, analisis induktif-deduktif. Hasil dari penelitian ini menunjukkan bahwa kontekstualisasi pembelajaran Filsafat IImu pada program Magister Psikologi dapat dilakukan melalui pendekatan inovatif dan kreatif.
\end{abstract}

Kata Kunci: filsafat ilmu; psikologi; pembelajaran; model.

\begin{abstract}
Philosophy of Science is one of the compulsory courses held for the Psychology master study program at Mercu Buana University Yogyakarta. Basically, the Philosophy of Science is an important part of learning for first semester students at the undergraduate and postgraduate levels in tertiary institutions as a foundation for knowing, understanding, and exploring certain fields of study. Philosophy of Science as a special branch of philosophy has a function and role to be the basis for providing an ontological, epistemological, and axiological framework for existing and developing science today. Philosophy of Science is taught at the Strata 2 as an effort to provide a framework for developing and exploring more specific and in-depth disciplines. This research is a form of classroom action research that will describe the learning process of the Philosophy of Science in the Psychology Masters Program at Mercu Buana University in the period 2020 to 2021. The purpose of this research is to provide an orientation and introduction to the philosophy of science learning model in the Strata program at the Mercu Buana University Yogyakarta. The contextualization of learning Philosophy of Science for disciplines outside of Philosophy is important. This research method uses qualitative methods. Sources of data used in this study use data sources from books, scientific journals, and the results of interviews with students. This data analysis uses critical analysis, inductive-deductive analysis. The results of this study indicate that the contextualization of the Philosophy of Science learning in the Psychology Masters program is carried out through an innovative and creative approach.
\end{abstract}

Keyword: philosophy of science; psychology; learning; model. 


\section{Pendahuluan}

Studi dan Kajian tentang Filsafat IImu belum terlalu banyak dikembangkan pada aspek pendidikan dan analisis kritis. Persoalan ilmu merupakan persoalan yang kompleks dalam bidang studi kritis. Ilmu berkembang sesuai dengan hasil produk pemikiran dan penemuan manusia dalam segala aspek kehidupan. Perkembangan ilmu terjadi karena proses pencarian (inquiry), penemuan (discovery), dan proses penelitian yang selalu berkelanjutan.

Pokok persoalan ilmu yang menjadi pusat perhatian sepanjang sejarah perkembangan ilmu ialah bagaimana mencapai kebenaran ilmiah, dengan cara apa kebenaran ilmiah itu dapat diuji dan dipastikan, bagaimana pengetahuan ilmiah dapat dikatakan memiliki pengakuan atau legitimasi secara universal. Apakah metode ilmiah bisa dipercaya dan dipertanggung jawabkan untuk mendapatkan pengetahuan yang benar atau kebenaran pengetahuan. Apakah kebenaran pengetahuan bersifat absolut atau relatif. Firman menjelaskan dalam sains juga muncul perdebatan dalam aspek kepastian dan ketidakpastian dalam sains. Maksud dari kepastian dan ketidakpastian dalam sains menurut Firman dalam klaim klaim sains terkait obyektivitas, universalitas, dan metodologi (Firman, 2019). Ketidakpastian dalam sains selalu dikaitkan dengan ketidakpastian metodologis dan ketidakpastian tentang kebenaran ilmiah. Firman juga menjelaskan bahwa ketidakpastian dalam sains terjadi pada dua arus utama yaitu ketidakpastian metodologis artinya, mempersoalkan bagaimana cara suatu ilmu atau pengetahuan dapat terbentuk. Kedua, ketidakpastian intrinsik, artinya terjadi karena struktur penggunaan gagasan ilmiah. Studi ini menyimpulkan bahwa kepastian dan ketidakpastian dalam sains selalu inheren atau melekat dalam fenomena sains (Firman, 2019).

Perdebatan tentang ilmu juga muncul dari aspek aksiologis. Pokok persoalan yang diperdebatkan ialah apakah ilmu itu bebas nilai atau tidak bebas nilai. Berbagai pandangan dan kelompok aliran filsafat dan pemikiran muncul dalam meletakkan pemahaman tentang dasar aksiologis ilmu ini antara bebas nilai dan tidak bebas nilai. Pada awal generasi, perdebatan ilmu muncul karena mempersoalkan pengetahuan yang benar bersumber dari apa dan mana? Perdebatan ini melahirkan aliran pemikiran empirisme dan rasionalisme. Damayanti dan Ma"ruf menyebutkan bahwa ilmu dan pengetahuan tidak lepas dari latar belakang sosial yang ada. Konsepsi teoritis dapat dianggap benar bukan karena ilmu itu memang benar pada dirinya sendiri melainkan karena dianggap benar oleh banyak orang karena berasal dari orang yang kuasa atau memiliki otoritas (Damayanti, S.N \& Ma"ruf, 2018). Krisis ilmu terjadi karena perdebatan cara pandang dalam melihat realitas. Realitas bisa dikatakan majemuk dan dapat dikatakan tunggal tergantung dari perspektif dalam meletakkan realitas tersebut. Beberapa kasus dapat ditunjukkan untuk mempersoalkan posisi kebenaran pengetahuan sebagai berikut: kasus pertama, sosialisasi 4 pilar kebangsaan atau 4 pilar MPR RI yang diselenggarakan oleh lembaga negara Majelis Permusyawaratan Rakyat Republik Indonesia mengatakan atau menjelaskan dalam berbagai sosialisasi yang diselenggarakan bahwa Pancasila, UUD 1945, NKRI, dan Bhinneka Tunggal Ika merupakan pilar. Kebenaran pengetahuan yang berasal dari otoritas kekuasaan sebagaimana yang dimaksud dari Damayanti dan Ma'ruf juga muncul dalam kasus atas pengetahuan 4 pilar yang terdiri atas Pancasila, UUD 1945, NKRI, dan Bhinneka Tunggal Ika. Kasus ini menjadi persoalan tentang sumber legitimasi pengetahuan dan metode mendapatkan pengetahuan karena dampak dari sosialisasi 4 pilar kebangsaan atau 4 pilar MPR RI pengetahuan tentang Pancasila, UUD 1945, NKRI, dan Bhinneka Tunggal Ika adalah pilar sebagai kebenaran umum. Pada aspek lain yang ditinjau dari dasar historis, yuridis, filosofis, dan sosiologis. Istilah itu tidak dapat dianggap sebagai kebenaran karena bertentangan dengan pengetahuan sejarah tentang Pancasila. Pancasila sejak dirumuskan dan disusun bukan sebagai pilar tetapi sebagai dasar negara. Persoalannya, kenapa MPR RI bisa menyebut menjadi pilar, hal ini menjadi persoalan epistemologi tentang kebenaran pengetahuan yang benar berasal dari mana? Selama ini otoritas atau penguasa melakukan pembenaran atas istilah pilar yang digunakan untuk menyebut Pancasila sebagai pilar. Problem penggunaan bahasa dapat menjadi problem filsafat ilmu yang saat ini berkembang menjadi polemic dan perdebatan di masyarakat. Untuk itu, studi tentang dinamika Filsafat IImu dalam proses pembelajaran menjadi penting secara khusus pada tingkat perguruan tinggi. Pendidikan tinggi memiliki skema untuk membentuk karakter dan keilmuan mahasiswa sesuai dengan standar berdasarkan Kualifikasi Kerangka Nasional Indonesia (KKNI) yang sudah dirumuskan oleh pemerintah dalam hal ini Kementerian Ristek Dikti. Berdasarkan dari dokumen yang diterbitkan oleh Dikti (2015) terdapat 6 paramater $\mathrm{KKNI}$, yaitu: (a) Ilmu pengetahuan (science), (b) pengetahuan (knowledge), (c) pengetahuan prakatis (know-how), (d) keterampilan (skill), (e) afeksi (affection), 
dan (f) kompetensi (competency). Jenjang parameter ini sebagai acuan dalam merumuskan capaian dan luaran lulusan dari perguruan tinggi mulai dari strata 1 sampai dengan strata 2. Dalam Peraturan Presiden Nomor 8 Tahun 2012 tentang Kerangka Kualifikasi Nasional Indonesia pasal 5 poin g menyebutkan bahwa lulusan Magister Terapan dan Magister paling rendah setara dengan jenjang 8 . Maksud dari jenjang 8 dijabarkan lebih lanjut untuk memiliki kompetensi antara lain: 1) Mampu mengembangkan pengetahuan, teknologi, dan/atau seni di dalam bidang keilmuannya atau praktek profesionalnya melalui riset, hingga menghasilkan karya inovatif dan teruji. 2) Mampu memecahkan permasalahan ilmu pengetahuan, teknologi, dan/atau seni di dalam bidang keilmuannya melalui pendekatan inter atau multidisipliner. 3) Mampu mengelola riset dan pengembangan yang bermanfaat bagi masyarakat dan keilmuan, serta mampu mendapat pengakuan nasional dan internasional (Perpres No.8/2012 tentang Kerangka Kualifikasi Nasional).

Pembelajaran pada jenjang Magister pada dasarnya diarahkan untuk dapat mencapai standar KKNI yang telah ditetapkan oleh pemerintah. Berbagai upaya untuk mendukung standar tersebut pengembangan kurikulum di perguruan tinggi secara khusus pada jenjang magister diarahkan dapat mendorong mahasiswanya dapat mencapai standar yang ada melalui berbagai macam pembelajaran dan kegiatan yang ada. Misalnya pada program Magister Psikologi Universitas Mercu Buana Yogyakarta memiliki program studi yang terdiri atas prodi profesi dan sains. Untuk Prodi Profesi, dibagi menjadi tiga fokus studi, yaitu klinis, pendidikan, dan psikologi industri dan organisasi. Universitas Mercu Buana Yogyakarta secara umum tidak memiliki Program Studi Filsafat atau Fakultas Filsafat, namun beberapa fakultas atau program studi memiliki kurikulum yang mencantumkan pembelajaran terkait dengan filsafat antara lain filsafat umum, filsafat imu, filsafat pendidikan, dan logika. Filsafat Ilmu pada Magister Psikologi Universitas Mercu Buana Yogyakarta merupakan mata kuliah yang ditawarkan sebagai mata kuliah wajib pada semester 1 untuk program Magister Psikologi Universitas Mercu Buana Yogyakarta dengan bobot 2 SKS. Mata kuliah ini diperuntukkan untuk Program Studi Klinis, Pendidikan, Psikologi Industri dan Organisasi, serta Sains. Mata kuliah Filsafat IImu diberikan pada semester 1 karena termasuk mata kuliah umum nonprofesi. Mata kuliah pada semester 1 merupakan mata kuliah yang dikelompokkan sebagai mata kuliah kemagisteran, sedangkan pada semester 2 mata kuliah lebih diarahkan untuk mata kuliah teori keprofesian, sedangkan untuk semester 3 sudah mulai pada Praktek Kerja Profesi Psikologi bagi prodi profesi. Untuk semester 4 dan 5, sudah mulai menyusun tesis atau tesis. Tulisan ini akan memaparkan tentang bagaimana kontekstualisasi filsafat ilmu pada program Magister Psikologi di Universitas Mercu Buana Yogyakarta yang dikembangkan dan berkembang. Kontekstualisasi dimaksudkan sebagai upaya untuk menempatkan pada situasi dan kondisi yang diharapkan, sehingga tidak terjadi kesenjangan dalam pengetahuan dan praktek tetapi menjadi satu kesatuan pada program Magister Psikologi atau ilmu Psikologi. Bagaimana problem yang muncul dalam ilmu yang berkembang di lingkungan mahasiswa Magister Psikologi. Seperti apa model pengajaran filsafat ilmu yang dikembangkan di Magister Psikologi untuk mengatasi persoalan persoalan yang muncul di kelas filsafat ilmu. Penelitian ini urgen untuk dilakukan karena sampai sejauh ini masih terbatas literature yang membahas dan menguaraikan tentang model dan kontekstualisasi pembelajaran filsafat ilmu pada disiplin ilmu lain seperti Psikologi. Keterbatasan literatur dan hasil penelitian yang tidak terlalu banyak ditemukan menjadikan penelitian ini sebagai dasar untuk dapat mengembangkan penelitian berkaitan dengan kontekstualisasi filsafat IImu dalam bidang disiplin ilmu lain.

\section{Metode}

Penelitian ini merupakan penelitian kualitatif. Bahan penelitian diperoleh melalui studi literatur tentang Filsafat IImu sebagai salah satu mata kuliah yang diajarkan pada jenjang pendidikan yang bersifat nonfilsafat. Periode studi ini dilakukan pada semester 2019/2020 dan 2020/2021 untuk kelas mata kuliah Filsafat IImu pada Program Studi Magister Psikologi Universitas Mercu Buana Yogyakarta. Penelitian ini dipilih sebagai upaya untuk mendeskripsikan proses pembelajaran di kelas dengan tujuan untuk menunjukkan kontekstualisasi pembelajaran Filsafat IImu yang ada, serta meningkatkan kualitas pembelajaran para mahasiswa dalam memahami Filsafat IImu. Sumber data diperoleh melalui wawancara, observasi kelas, dan dokumen pembelajaran kegiatan kelas serta studi buku, jurnal ilmiah, silabus, dan kurikulum Filsafat IImu. Data yang dikumpulkan dikategorikan dan dibuat kode dari hasil proses pengumpulan data. Kemudian di analisis. Analisis data menggunakan pendekatan analisis 
induktif-deduktif, heuristika, dan refleksi kritis. Analisis induktif-deduktif, berupaya untuk menggali data dan informasi dari fenomena dan peristiwa yang terjadi pda lingkup kecil untuk ditarik kesimpulan umum. Metode heuristika, sebagai salah satu bentuk analisis untuk menemukan sesuatu yang baru dari hasil data yang dianalisis. Metode refleksi kritis ini diarahkan untuk mengekplorasi hasil pengalaman untuk dideskripsikan dan diuraikan.

\section{Hasil dan Pembahasan}

Filsafat IImu merupakan salah satu cabang Filsafat khusus memiliki peran penting dalam memberikan dasar berpikir dan berpijak untuk memahami hakikat ilmu. Filsafat ilmu merupakan upaya untuk menjelaskan masalah-masalah terkait dengan apa dan bagaimana ilmu itu, serta bagaimana metode ilmiah dapat digunakan untuk mendapatkan pengetahuan yang sahih (Hermawan, 2015). Filsafat IImu merupakan bagian dari studi kritis yang tidak banyak menjadi perhatian. Pandangan Roza dan Sulistyaningtyas menyebutkan bahwa Filsafat ilmu sebagai salah satu cabang ilmu filsafat dapat dipandang dari dua pendekatan yaitu pertama, sebagai disiplin ilmu dalam bidang filsafat. Kedua, sebagai landasan filosofis proses keilmuan. Filsafat ilmu memiliki obyek kajian ilmu pengetahuan dan menjadi kerangka dalam proses penggalian ilmu atau memberikan perspektif untuk melihat hakikat ilmu serta landasan filosofisnya (Roza \& Sulistyaningtyas, 2006). Filsafat ilmu dalam pandangan lain juga dilihat sebagai bentuk pertautan antara aktivitas ilmiah, metode ilmiah, dan pengetahuan sistematis (Achadah \& Fadil, 2020).

Selama ini Filsafat ilmu hanya meletakkan pada basis ontologis, epistemologis, dan aksiologis dalam memahami dan menjelaskan fenomena ilmu dan pengetahuan yang berkembang. Pada Jurnal Filsafat Indonesia periode tahun 2018 sampai dengan 2020 kajian dan studi tentang Filsafat ilmu belum banyak muncul dari artikel yang masuk. Salah satu naskah yang membahas terkait dengan Filsafat Ilmu ialah Shidiq dengan judul "Filsafat Sains: Inferensi dan Eksplanasi Ilmiah pada Awal Perkembangan Spektroskopi Serapan Atom", dalam tulisan ini diuraikan terkait dengan analisis Filsafat ilmu dari aspek proses penalaran ilmiah dan penjelasan dalam fenomena Spektroskopi Serapan Atom (SSA). Kajian ini menarik karena menggunakan pendekatan filsafat ilmu yang diistilah oleh Shidiq sebagai Filsafat Sains untuk menguraikan fenomena SSA. Kajian ini menunjukkan bahwa pendekatan eksplanasi terhadap fenomena SSA dapat dilakukan melalui proses inferensi induktif dan deduktif. Proses penalaran dan penjelasan induktif dan deduktif ini dapat melengkapi dan menguraikan tentang gejala SSA atau kasus ilmiah tertentu yang saling melengkapi (Shidiq, 2019). Filsafat IImu dapat dikatakan sebagai pendekatan dan juga sebagai metode untuk mendapatkan hakikat dan kebenaran ilmiah. Pada perspektif pertama, filsafat ilmu sebagai pendekatan sering digunakan untuk menganalisis suatu obyek tertentu. Analisis Amsad tentang tinjauan penalaran ilmliah yang dilakukan untuk membaca dan menganalisis temuan temuan Sains yang tak disengaja (serendipity). Amsad menjelaskan bahwa penemuan tak terduga memiliki dampak yang penting dalam proses dalam pembelajaran sains. Penemuan tak terduga ini dapat dikategorikan menjadi dua aspek yaitu penemuan tak terduga secara murni dan temuan tak terduga secara pseudo. Studi ini mencoba untuk menjawab cara dan metode penalaran ilmiah yang selama ini berkembang dari dua tradisi paradigma utama yaitu penalaran ilmiah berpijak pada induktif (empirik) dan penalaran ilmiah berpijak pada deduktif. Salah contoh penemuan yang tak disengaja dalam bidang biologi ialah penemuan pinisilin yang dilakukan oleh Flemming, penemuan struktur DNA yang dilakukan oleh James Watson dan Francis Crick, penemuan vaksinasi cacar oleh Edwar Jenner serta berbagai penemuan di bidang fisika seperti Sinar X, elektromagnitis, dan lain-lain. Penalaran ilmiah pada dasarnya menjadi penting dalam proses untuk mendapatkan penemuan ilmiah yang tak disengaja tetapi berdampak besar dalam perkembangan ilmu pengetahuan. Proses untuk mendapatkan penemuan ilmiah yang tak disengaja karena ada proses penalaran ilmiah yang dilakukan oleh peneliti melalui proses pemahaman atas kasus kasus yang khusus yang kemudian dapat digeneralisasikan menjadi kesimpulan umum. Namun, hal itu dapat terjadi melalui pengujian atas hipotesis hipotesis melalui serangkaian eksperimentasi yang kemudian menghasilkan penemuan yang tak disengaja (Amsad, 2019). Dalam kajian lain menunjukkan bahwa filsafat ilmu dilihat sebagai landasan dalam pengembangan ilmu lain secara khusus ilmu pendidikan. Menurut Widyawati, filsafat ilmu memliki sejumlah manfaat yang dapat membantu pembelajar dalam memahami tentang ilmu karena dalam proses pembelajaran filsafat ilmu pembelajar didorong untuk berlatih berfikir radikal tentang hakikat ilmu, berpikir reflektif, dan menghindari dari kemutlakan kebenaran ilmiah, serta menghindari diri dari egoisme ilmiah (Widyawati, 2013:94). Lebih lanjut, ia menguraikan bahwa Filsafat ilmu dapat memiliki peran dalam memberikan landasan pengembangan ilmu pendidikan 
karena persoalan persoalan dalam ilmu pendidikan berkaitan erat dengan topik topik pembahasan dalam filsafat ilmu seperti masalah metafisis, epistemologi, metodologis, logika, etika, dan estetika (Widyawati, 2013:95). Kajian yang dilakukan Lako menyebutkan bahwa peran Filsafat IImu dalam bidang disiplin ilmu lain seperti Akuntansi dianggap memiliki peran yang cukup signifikan. Filsafat ilmu dianggap berperan dalam meletakkan dasar paradigmatik ilmu akuntansi karena dalam filsafat ilmu mencari sebab sebab pertama dan mendalam tentang fenomena kehidupan sehari hari, menggali kebenaran, kepastian, obyektivitas, abstraksi, intuisi, dan dari mana asal dan kemana arah pengetahuan. Dalam bidang akuntansi, filsafat ilmu memiliki peran karena dapat membantu merumuskan postulat-postulat serta asumsi asumsi dasar. Dari aspek epistemologisnya dapat memberikan gambaran dan dasar dasar metodis, prinsip prinsip, dan standar instrumen (Lako, 2004:167). Wahana menjelaskan bahwa ilmu pengetahuan (atau pengetahuan ilmiah) merupakan salah satu unsur yang sangat penting dalam kehidupan masyarakat karena ilmu pengetahuan sebagai dasar untuk perencanaan, pengaturan, penataan, dan penyelenggaraan kehidupan masyarakat (Wahana, 2016). Pada program studi Magister Psikologi memiliki struktur kurikulum yang ringkas dan ramping. Berikut ini tabel Kurikulum Magister Psikologi Universitas Mercu Buana Yogyakarta:

Tabel 1. Kurikulum Mata Kuliah Wajib Kemagisteran Magister Psikologi

\begin{tabular}{|c|c|c|}
\hline No & $\begin{array}{c}\text { Nama Mata Kuliah } \\
\text { Mata Kuliah Wajib Kemagisteran (32 } \\
\text { SKS) }\end{array}$ & SKS \\
\hline 1. & Filsafat IImu & 2 \\
\hline 2. & Metodologi Penelitian Kuantitatif & 2 \\
\hline 3. & Metodologi Penelitian Kualitatif & 2 \\
\hline 4. & Statistik Inferensial & 2 \\
\hline 5. & $\begin{array}{l}\text { Penyusunan dan Pengembangan Alat } \\
\text { Ukur }\end{array}$ & 2 \\
\hline 6. & Psikologi Sosial Lanjut & 2 \\
\hline 7 & Psikologi Motivasi & 2 \\
\hline 8 & Psikologi Kepemimpinan & 2 \\
\hline 9 & $\begin{array}{l}\text { Berbagai Pendekatan Teoritis dalam } \\
\text { Psikologi }\end{array}$ & 4 \\
\hline 10 & Psikologi Lintas Budaya & 2 \\
\hline 11 & Kode Etik Psikologi & 2 \\
\hline 12 & Tesis & 8 \\
\hline
\end{tabular}

Sumber: Panduan Akademik Magister Psikologi, 2017.

Tabel di atas tentang Kurikulum Mata Kuliah Wajib Kemagisteran Magister Psikologi menunjukkan bahwa mata kuliah bidang Filsafat khususnya Filsafat Ilmu merupakan satusatunya mata kuliah yang dimasukkan dalam mata kuliah wajib kemagisteran pada Magister Psikologi di Universitas Mercu Buana Yogyakarta. Mata kuliah ini dianggap menjadi mata kuliah dasar untuk memasuki jenjang sebagai seorang mahasiswa Magister. Sebagaimana dalam standar Kualifikasi Kerangka Nasional Indonesia (KKNI) yang telah ditetapkan pemerintah. KKNI untuk lulusan Magister terapan dan magister paling rendah setara dengan jenjang 8 , yaitu memiliki kompetensi mampu mengembangkan pengetahuan, teknologi, dan bidang keilmuannya serta menghasilkan karya inovatif dan teruji. Selain itu, mampu memecahkan masalah ilmu pengetahuan, teknologi dalam bidang keilmuan melalui pendekatan interdisipliner dan multidisipliner, mampu mengelola riset yang dapat mengembangkan keilmuan yang dapat bermanfaat bagi masyarakat dan ilmu serta mampu mendapat pengakuan nasional dan internasional. Terkait dengan persoalan filsafat ilmu ditemukan beberapa karakteristik persoalan tentang ilmu khususnya menyangkut bidang ilmu psikologi yang dihadapi oleh masing masing disiplin ilmu baik pada profesi maupun sains. Untuk profesi, terdapat tiga kategori minat studi, yaitu klinis, pendidikan, dan psikologi industri dan organisasi. Kasus di kelas terkait dengan materi yang berkaitan dengan ilmu yang terjadi ialah keterputusan pengetahuan antara penerima (mahasiswa) dan pemberi materi (dosen). Proses pemahaman dan pengalaman dalam materi yang dikuasai menjadi salah satu penghambat dalam aspek penerimaan pengetahuan dan pemahaman tentang materi yang disampaikan. Isu isu keilmuan di bidang studi yang digeluti 
tidak secara benar benar dikuasai dengan baik atau kurang mendapatkan informasi terkait dengan isu isu terkini tentang bidang ilmu yang dilakukan menjadikan persoalan dalam memberikan pengetahuan di kelas. Berdasarkan dari hasil penelitian tentang persoalan persoalan ilmu di bidang Magister Psikologi dari masing masing prodi dapat dikategorikan sebagai berikut:

Tabel 2. Persoalan Ilmu berdasarkan pada minat studi

\begin{tabular}{|c|c|c|c|c|c|}
\hline No & Aspek & Klinis & Pendidikan & PIO & Sains \\
\hline 1 & Ontologis & $\begin{array}{l}\text { - Hakikat } \\
\text { jiwa/kejiwa } \\
\text { an } \\
\text { - Perilaku } \\
\text { individu } \\
\text { berkaitan } \\
\text { dengan } \\
\text { kondisi } \\
\text { psikis dan } \\
\text { biologis }\end{array}$ & $\begin{array}{l}\text { - Pembelajaran } \\
\text { siswa } \\
\text { (hakikat } \\
\text { belajar dan } \\
\text { siswa) } \\
\text { - Hakikat pola } \\
\text { asuh anak } \\
\text { - Pola atau } \\
\text { fase } \\
\text { perkembang } \\
\text { an siswa }\end{array}$ & $\begin{array}{l}\text { - Memahami } \\
\text { hakikat } \\
\text { manusia (homo } \\
\text { Faber) } \\
\text {-Eksistensi } \\
\text { manusia dalam } \\
\text { dunia kerja } \\
\text { (sumber daya } \\
\text { manusia) } \\
\text {-Sistem tata } \\
\text { kelola SDM }\end{array}$ & $\begin{array}{l}\text { - Masyarakat } \\
\text { - Ilmu Psikologi } \\
\text { dalam menjawab } \\
\text { persoalan } \\
\text { masyarakat }\end{array}$ \\
\hline 2 & Epistemologis & $\begin{array}{l}\text { - Metode } \\
\text { menangani } \\
\text { perilaku } \\
\text { individu } \\
\text { - Metode } \\
\text { yang } \\
\text { beragam } \\
\text { dengan } \\
\text { pendekata } \\
\text { n yang } \\
\text { berbeda }\end{array}$ & $\begin{array}{l}\text { - Efektivitas } \\
\text { metode } \\
\text { intervensi } \\
\text { - Sistem dan } \\
\text { metode } \\
\text { pengajaran } \\
\text { - Metode } \\
\text { menangani } \\
\text { siswa }\end{array}$ & $\begin{array}{l}\text { - Cara } \\
\text { Mengelola } \\
\text { manusia } \\
\text { dalam dunia } \\
\text { kerja } \\
\text { - Pengelolaan } \\
\text { SDM }\end{array}$ & $\begin{array}{l}\text { - Paham dan } \\
\text { pendekatan } \\
\text { metodis/metodolo } \\
\text { gis dalam } \\
\text { menjawab } \\
\text { persoalan } \\
\text { masyarakat }\end{array}$ \\
\hline 3 & Aksiologis & $\begin{array}{l}\text { - Nilai hidup } \\
\text { Penemuan } \\
\text { jati diri }\end{array}$ & $\begin{array}{l}\text { - Nilai } \\
\text { perkembang } \\
\text { an siswa } \\
\text { - Nilai kognitif, } \\
\text { nilai emosi } \\
\text { - Nilai perilaku }\end{array}$ & $\begin{array}{l}\text { - Nilai } \\
\text { pemenuhan } \\
\text { - Nilai } \\
\text { kebahagiaan } \\
\text { - Nilai } \\
\text { kesejahteraan }\end{array}$ & $\begin{array}{l}\text { - Nilai } \\
\text { keseimbangan } \\
\text { - Nilai } \\
\text { keharmonisan } \\
\text { - Perdebatan } \\
\text { standarisasi nilai } \\
\text { individu dan nilai } \\
\text { sosial }\end{array}$ \\
\hline
\end{tabular}

Sumber: diolah dari hasil analisis penelitian, 2021

Tabel di atas menunjukkan bahwa persoalan ilmu yang mendasar dalam perspektif Filsafat Ilmu yang teridentifikasi melalui hasil kajian pustaka dan wawancara terhadap mahasiswa yang mengambil bidang minat studi klinis, pendidikan, psikologi industri dan organisasi (PIO) dan sains dapat dipetakan sebagaimana tabel di atas. Pada aspek ontologis, persoalan ilmu yang muncul pada kelas klinis membahas dan mempersoalkan tentang hakikat jiwa dan kejiwaan, serta perilaku manusia. Untuk studi pendidikan, menekankan pada aspek hakikat belajar dan anak dalam proses pembelajaran dan hakikat pola asuh orang tua dalam mendidik. Untuk PIO menekankan pada hakikat manusia sebagai homo faber dan tata kelola sumber daya manusia, sedangkan sains menekankan pada masyarakat dan ilmu psikologi. Pada aspek epistemologis, minat studi klinis memaparkan perdebatan yang muncul terkait keberagaman metode dan pendekatan yang digunakan dalam menangani persoalan klinis. Minat studi pendidikan memperdebatkan persoalan efektivitas metode intervensi. Untuk PIO, memfokuskan pada cara mengelola sumber daya manusia. Sedangkan untuk sains perdebatan penggunaan paham atau aliran dalam menangani persoalan masyarakat. Pada aspek aksiologis, minat bidang klinis mempersoalkan tentang nilai hudup, dan penemuan jati diri. Minat studi pendidikan menekankan pada nilai nilai intelektual. Minat studi PIO lebih memfokuskan pada nilai kebahagiaan, nilai pemenuhan, dan kesejahteraan. Pada minat Sains membahas tentang standarisasi nilai individu 
dan sosial. Persoalan persoalan ilmu yang telah diidentifikasi secara umum sebagaimana tabel di atas menjadi bahan dasar dalam pengembangan pembelajaran filsafat ilmu. Filsafat ilmu merupakan studi untuk menggali aspek aspek terdalam dalam ilmu. Misalnya aspek ontologis, aspek epistemologis, dan aspek aksiologis. Identifikasi persoalan ilmu pada minat studi yang ada menjadi penting karena hasil dari identifikasi awal ini akan menjadi bagian dari obyek kajian filsafat ilmu. Sebagaimana dalam ruang lingkup filsafat ilmu yang telah dirumuskan oleh berbagai ahli menyebutkan bahwa ruang lingkup filsafat ilmu akan menelaah berbagai konsep, asumsi, metode ilmu, dan sebab dan akibat pengetahuan ilmiah bagi manusia dan ilmu itu sendiri. Selain itu, filsafat ilmu juga menelaah kebenaran dan validitas pengetahuan yang dimiliki oleh manusia (Susanto,2016:56). Kegiatan identifikasi ini menjadi bagian penting untuk mendapatkan gambaran umum tentang persoalan mendasar dalam ilmu yang dimiliki pada bidang psikologi.

Kontekstualisasi pembelajaran filsafat ilmu dalam bidang ilmu Magister Psikologi menjadi penting. Pengertian kontekstualisasi mengarahkan pada cara pemberian dan pemilihan materi Filsafat ilmu untuk disesuaikan dengan kebutuhan program studi. Materi filsafat ilmu merupakan materi untuk bidang filsafat secara umum dan khusus. Filsafat ilmu meskipun dapat digunakan untuk menjadi materi pada bidang ilmu yang lain perlu disesuaikan dengan kebutuhan dari mahasiswa program studi yang ada serta disesuaikan dengan standar KKNI. Berdasarkan dari studi literatur yang dilakukan berbagai referensi atau literatur yang berkembang untuk menjadi rujukan filsafat ilmu secara umum dapat ditemukan dari buku, jurnal ilmiah, dan media visual youtube tentang sejarah ilmu, sejarah filsafat, sejarah filsafat ilmu, serta sejarah pemikiran filsafat ilmu. Tema tema khusus juga diperkenalkan dalam pembelajaran filsafat ilmu antara lain: persoalan-persoalan dalam filsafat ilmu, dasar dan jenis ilmu pengetahuan, kebenaran, hakikat metode ilmiah, dan penalaran ilmiah, Ontologi, epistemologi, dan aksiologi dalam ilmu. Tema tema tersebut menjadi tema umum dalam buku rujukan yang ditulis dan berkembang selama ini di Indonesia. Untuk itu, berbagai referensi tentang filsafat ilmu memiliki cara pandang dan pendekatan dalam menyajikan topik dan isu isu tentang filsafat ilmu.

Materi pembelajaran yang diberikan untuk program studi Magister Psikologi pada Universitas Mercu Buana Yogyakarta sebagai berikut.

Tabel 3. Silabus Filsafat Ilmu pada Magister Psikologi UMBY.

\begin{tabular}{ll}
\hline No & \multicolumn{1}{c}{ Pokok Materi } \\
\hline 1. & Pengantar filsafat dan dasar-dasar berpikir filsafati \\
\hline 2. & Persoalan persoalan filsafat \\
\hline 3. & Cabang cabang filsafat \\
\hline 4. & Obyek studi filsafat dan ilmu pengetahuan \\
\hline 5. & Sejarah Ilmu dan Persoalan dalam filsafat ilmu \\
\hline 6. & Hubungan filsafat, Ilmu, dan filsafat Ilmu \\
\hline 7. & Landasan ontologis, epistemologis, aksiologis \\
\hline 8. & dalam filsafat ilmu \\
\hline 9. & Stradigma dan pendekatan dalam metode ilmu \\
\hline 10. & Kebenaran ilmiah \\
\hline 11. & Moralitas, etika, nilai dan kegunaan ilmu \\
\hline 12. & Paradigma pengembangan ilmu \\
\hline 13. & Obyektivitas dan subyektivitas dalam Ilmu \\
\hline 14. & Perubahan dan perkembangan Ilmu \\
\hline 15. & Filsafat ilmu dan psikologi \\
\hline & Sumber: Silabus perkuliahan Filsafat ilmu,2020.
\end{tabular}

Berdasarkan dari tabel di atas, materi pembelajaran Filsafat IImu diarahkan untuk memberikan pengetahuan dan kerangka dasar tentang Filsafat IImu sebagai dasar dalam pengembangan keilmuan yang lebih khusus seperti bidang ilmu psikologi. Berdasarkan hasil observasi di kelas, bahwa setiap peserta atau mahasiswa yang mengikuti perkuliahan Filsafat ilmu atau pada program studi Magister Psikologi memiliki latar belakang keilmuan yang beragam, khususnya dari Magister Psikologi Sains tidak selalu berasal dari latar belakang psikologi, sedangkan untuk minat studi profesi memang pada dasarnya berasal dari latar belakang pendidikan psikologi atau ilmu psikologi. Namun, yang membedakan adalah para mahasiswa dari 
Magister Psikologi Profesi seperti klinis, pendidikan, dan PIO meskipun memiliki latar belakang bidang ilmu psikologi pada jenjang sarjana. Mereka berasal dari berbagai macam perguruan tinggi baik dari dalam kota maupun luar kota. Latar belakang perguruan tinggi yang berbeda ini menjadi persoalan tersendiri dari proses pembelajaran Filsafat IImu karena belum tentu mahasiswa yang berasal dari perguruan tinggi asal pernah mendapatkan mata kuliah Filsafat secara umum atau mata kuliah filsafat secara khusus seperti filsafat IImu, filsafat Umum, filsafat pendidikan, atau filsafat psikologi sehingga perlu ada upaya untuk menyamakan persepsi dari mahasiswa tentang pengertian filsafat secara umum dan sejarahnya. Setelah memberikan pemahaman secara umum kepada mahasiswa tentang filsafat, kemudian mulai menjabarkan dan menjelaskan tentang filsafat ilmu mulai dari pengertian, ruang lingkup, obyek formal, dan obyek material dalam filsafat ilmu, persoalan persoalan dalam filsafat ilmu. Upaya kontekstualisasi filsafat ilmu dalam pembelajaran di Magister Psikologi Universitas Mercu Buana Yogyakarta dalam bentuk kegiatan kelas dan penugasan mandiri. Kontekstualisasi yang dilakukan ialah pertama, merumuskan tema-tema dalam kegiatan kelas dan penugasan mandiri diarahkan untuk lebih mendorong mahasiswa dalam membangun dasar dasar keilmuan dalam bidang psikologi sesuai dengan peminatan yang dipilih. Kedua, materi filsafat ilmu diarahkan untuk menjadi dasar dan pendekatan dalam menggali aspek aspek terdalam dan mendasar dalam bidang ilmu yang dipelajari secara khusus ilmu psikologi. Ketiga, materi filsafat ilmu sebagai mata kuliah Filsafat, untuk bidang ilmu Psikologi disesuaikan dengan konteks atau dikaitkan dengan materi bidang psikologi sehingga bukan murni materi filsafat IImu sebagaimana yang dibahas dan dikaji dalam perkuliahan Program Studi IImu Filsafat. Pada masa pandemi ini, bentuk kegiatan kelas dan penugasan juga dilakukan melalui daring dengan media yang sudah disediakan oleh kampus. Mahasiswa juga diperkenalkan dalam pembelajaran filsafat IImu melalui review video pembelajaran tentang sejarah ilmu, pemikiran pemikiran di bidang filsafat ilmu, para filsuf yang berperan penting dalam melahirkan teori, konsep, dan paradigma keilmuan tertentu. Dari aspek untuk mendorong sikap kritis dan analitik mahasiswa, mahasiswa diberikan materi dan bahan bacaan dari jurnal baik nasional dan internasional terpilih untuk dapat melihat perspektif lebih luas tentang pemikiran dan cara berpikir Filsafat IImu yang ada di dalam dan luar negeri. Pendalaman yang diberikan agar mahasiswa bisa lebih mencerna dan mendalami tentang filsafat IImu dilakukan melalui pembuatan peta konsep dari materi yang sudah ditentukan dan mereview beberapa artikel terpilih secara bertahap atau tematis. Kontekstualisasi kajian dan materi yang digunakan memfokuskan pada materi filsafat IImu yang mengarah pada pemahaman tentang hakikat ilmu, penggunaan metode dalam ilmu, dan pengembangan teori filsafat IImu untuk ilmu psikologi. Tujuan ini untuk meletakkan peran dan fungsi mahasiswa dalam proses pembelajaran aktif, analitik, dan kritis. Untuk evaluasi pembelajaran, digunakan dengan cara hasi penugasan terstruktur dan sistematis, ujian tengah semester berupa tinjauan dan analisis atas kasus atau persoalan terkait Filsafat ilmu dan psikologi, serta ujian akhir semester dalam bentuk penulisan karya tulis sederhana untuk mengukur kompetensi keilmuan dalam menguraikan dan menjabarkan secara ilmiah tentang topik tertentu. Kedalaman analisis ini yang akan dilihat dan rujukan rujukan yang digunakan menjadi pertimbangan dalam proses penilaian dan evaluasi pembelajaran filsafat ilmu. Evaluasi yang digunakan dalam proses pembelajaran ini dapat terlihat dari hasil uraian yang disampaikan oleh mahasiswa dari aspek pemahaman, penalaran, dan pemaknaan akan materi filsafat ilmu menjadi lebih terbuka dan mendalam

\section{Simpulan dan Saran}

Kontekstualisasi pembelajaran filsafat ilmu pada program Magister Psikologi di Universitas Mercu Buana Yogyakarta telah dikembangkan dalam berbagai bentuk yang inovatif dan kontesktual. Bentuk inovatif yang diperkenalkan dalam proses pembelajaran dapat ditunjukkan dari materi, pendekatan, metode, dan bahan ajar yang telah disiapkan oleh tim dosen dalam mempersiapkan materi pembelajaran Filsafat Ilmu untuk program Magister Psikologi. Selain itu, bentuk kontekstual yang lain dapat dilihat dari tema tema yang diberikan disesuaikan dengan tema tema minat studi yang diambil dari masing masing dosen. Filsafat ilmu menjadi penting dalam meletakkan fondasi keilmuan bagi mahasiswa Magister Psikologi, untuk itu proses pengembangan materi ajar dan metode belajar secara terus menerus untuk dapat dilakukan pembaharuan. 


\section{Ucapan Terimakasih}

Peneliti mengucapkan terima kasih atas kesempatan yang diberikan oleh Magister Psikologi Universitas Mercu Buana Yogyakarta yang telah memberikan ruang bagi peneliti untuk mengajar di Program Studi Magister Psikologi. Peneliti juga tidak lupa mengucapkan terima kasih kepada Karen Savitri, Dewi Wulandari, Fitroh Adi Putra, Prastika, Agung Putra Wijaya, Ade Eva Fatmawati, dan Laila M I W, yang telah memberikan informasi yang berharga dalam proses penelitian ini.

\section{Daftar Pustaka}

Achadah.A \& Fadil.M.(2020). Filsafat Ilmu: Pertautan Aktivitas Ilmiah, Metode Ilmiah dan Pengetahuan Sistematis.Jurnal Pendidikan Islam, Vol. 4, No. 1, Juni 2020, Hal. 130-141.

Amsad.N.L.(2019). Tinjauan Penalaran Ilmiah Pada Penemuan-Penemuan SainsYang Tak Disengaja (Serendipity). Jurnal Filsafat Indonesia, Vol 2 No 1 2019.hal.12-19.

Direktorat Jendral Pembelajaran dan KemahasiswaanKementerian Riset, Teknologi, dan Pendidikan TinggiRepublik Indonesia. (2015). Kerangka Kualifikasi Nasional Indonesia. Jakarta: Dirjen Dikti.

Damayanti, S. N \& Ma"ruf, H.M. (2018). Epistemologi Saintifik Thomas S. Kuhn terhadap Munculnya IImu Pengetahuan Sosial.Jurnal Filsafat Indonesia, Vol 1 No 3 2018, hal.120-127.

Firman.H.(2019). Kepastian dan Ketidakpastian dalam Sains.Jurnal Filsafat Indonesia, Vol 2 No 1 2019. Hal.33-36.

Hermawan. (2015). Perjalanan Singkat dan Perkembangan Filsafat Ilmu. Jurnal Theologia Vol.2 6 No.1, Tahun 2015.

Lako.A.(2004). Peran Filsafat Ilmu sebagai Fondasi Utama dalam Pengembangan Ilmu (Teori) Akuntansi. Jurnal Bisnis Akuntansi, Vol.2. No.2 Agustus 2004, 167-188.

Peraturan Presiden. (2012).Peraturan Presiden Nomor 8 Tahun 2012 tentang Kerangka Kualifikasi Nasional Indonesia.

Susanto. (2016). Filsafat Ilmu Suatu Kajian dalam Dimensi Ontologis, Epistemologis, dan Aksiologis. Cetakan ketujuh, Jakarta: Bumi Aksara.

Roza.P \& Sulistyaningtyas. (2006). Resensi Buku: Kajian Atas Asumsi Dasar, Paradigma, dan Kerangka Teori Ilmu Pengetahuan. Jurnal Sosioteknologi Edisi 7 Tahun 5, April 2006,56-60.

Shidiq.A.S.(2019). Filsafat Sains: Inferensi dan Eksplanasi Ilmiah pada Awal Perkembangan Spektroskopi Serapan Atom, Jurnal Filsafat Indonesia, Vol 2 No 1 2019.hal.20-26.

Wahana.P.(2016). Filsafat IImu Pengetahuan. Yogyakarta: Pustaka Diamond. 
Widyawati. S. (2013). Filsafat IImu Sebagai Landasan Pengembanganllmu Pendidikan. Gelar, Jurnal Seni dan Budaya, Volume 11 No. 1 Juli 2013. hal.87-96.

Internet:

https://s2-psikologi.mercubuana-yogya.ac.id/wp-content/uploads/2017/09/Kurikulum2017-Magister-Psikologi-Konversi-Mata-Kuliah.pdf. 